\title{
Meningkatkan Keterampilan Toilet Training Melalui Metode Latihan bagi Anak Autis
}

\author{
Nurul Afifah ${ }^{1}$, Megaiswari Biran Asnah ${ }^{2}$ \\ ${ }^{1}$ (Universitas Negeri Padang, Indonesia). \\ ${ }^{2}$ (Universitas Negeri Padang, Indonesia). \\ E-mail: nurul.affh@gmail.com
}

Receive: 13/05/2021

Accepted: 23/08/2021

Published: 01/10/2021

\begin{abstract}
Abstrak
Anak autis perlu membutuhkan perhatian yang khusus, salah satunya aktivitas sehari-hari yang membutuhkan kemandirian yaitu toilet training. Kemandirian toilet training pada anak autis sangatlah rendah karena disebabkan gangguan pada perkembangan yang berefek pada fungsi otaknya. Namun hal itu dapat ditingkatkan melalui metode pembelajaran yang tepat sesuai dengan kemampuannya. Penelitian ini bertujuan untuk meningkatkan keterampilan toilet training melalui metode latihan bagi anak autis kelas I SD di SDIT Luqman Padang. Metode yang digunakan dalam penelitian ini adalah metode eksperimen melalui pendekatan single subject research (SSR) dalam bentuk desain A-B-A. Teknik pengumpulan data yang digunakan yaitu melalui observasi, mengamati langsung perkembangan toilet training anak. Hasil penelitian menunjukkan bahwa metode latihan dapat meningkatkan keterampilan toilet training pada anak autis yang ditunjukkan dengan perubahan peningkatan kemampuan dari fase baseline (A1), intervensi (B) dan fase baseline (A2). Peningkatan kemampuan toilet training anak autis dapat dilihat dari persentase pencapaian yang diperoleh pada kemampuan awal (A1) anak mendapatkan 16\%, hasil intervensi (B) meningkat menjadi $72 \%$ dan hasil akhir baseline (A2) anak mendapatkan sebesar $88 \%$.
\end{abstract}

Kata Kunci: Pelatihan Toilet, Metode Latihan, Autis.

\begin{abstract}
Autistic children need special attention, one of the most self-sufficient everyday activities of self-reliance, the training toilet. The self-reliance toilet training in autistic children is very low because of developments that affect their brain function. But it can be enhanced by the proper learning methods it can afford. The study was to improve training toilet skills by training methods for elementary school children in SDIT Luqman Padang. The method used in the study is experimental methods through the design of the single subject research (SSR) approach $A-B-A$. The data collection technique used was by observation, by direct observation of the development of the child training toilet. Research shows that practice methods can improve toilet training skills on autic children shown with changes in the ability increased from the baseline (A1), the intervention (B) and the baseline (A2) phase. The increased ability of the autic toilet training children can be seen from the percentage of achievement obtained ata child's initial ability (A1) children get $16 \%$, the intervention results (B) go up to $72 \%$ and the baseline $(A 2)$ result gets $88 \%$.
\end{abstract}

Keywords: Toilet Training, Simulation, Autism.

\section{Pendahuluan}

Setiap anak pasti melakukan aktivitas buang air besar atau kecil, termasuk anak autis. Membuang air besar atau kecil merupakan kegiatan yang sangat penting karena bagian dari sistem ekskresi dalam tubuh. Secara ilmiah, sistem ekskresi ialah pengeluaran sisa-sisa metabolisme yang tidak diperlukan tubuh, berupa urine yang keluar dari saluran kemih dan fases melalui 
anus. Biasanya, anak autis belum mampu buang air besar atau kecil secara mandiri.

Anak autis biasanya menghadapi masalah kompleks termasuk gerakan indera, kognisi, interpersonal, hubungan, dan perawatan diri. Masalah yang sangat kompleks pada anak autis dapat menghambat segala aktivitas yang berhubungan dengan motorik, kognitif, sensorik dan khususnya aktivitas seharihari, dimana aktivitas tersebut memerlukan kemampuan kognitif dan koordinasi sensorimotor. Akibatnya, mereka tidak memiliki kemandirian untuk mengurus diri sendiri. Autis memiliki gangguan perkembangan yang berefek kepada fungsi normal dari otak. Autis dapat terjadi sejak lahir dan berefek kepada proses pembelajaran, kesulitan dalam berbahasa dan bersosialisasi, gangguan perkembangan yang memengaruhi fungsi otak, gangguan otak dapat terjadi sejak lahir, dan mengganggu perilaku serta proses pembelajaran (Irawan, 2019).

Toilet training merupakan rangkaian kegiatan pengembangan diri yang sangat rumit dibandingkan dengan yang lain. Dalam kegiatan tersebut, anak autis membutuhkan koordinasi anggota dan kemampuan orang lain. Koordinasi ini mencakup koordinasi antara gerakan tangan dan mata dan juga melibatkan keterampilan seperti melakukan urutan atau langkah-langkah kegiatan toilet training. Dibandingkan dengan anak normal pada umumnya, toilet training untuk anak autis membutuhkan waktu yang relatif lama. Dalam suatu kegiatan, anak mungkin hanya mampu melakukan satu tahap kegiatan toilet training, misalnya hanya bisa buang air kecil dan membuka celana air atau memasang celana (Khuriyati, 2014). Ada beberapa faktor yang dapat mempengaruhi pelaksanaan toilet training, (Syarifuddin, 2010) yaitu: (1) kesiapan fisik, mental dan psikologi anak, (2) kesiapan orang tua dalam membimbing anaknya, (3) rutinitas orang tua dalam mengajarkan toilet training, (4) tersedianya sarana dalam keluarga.

Pada penelitian ini peneliti memilih menggunakan metode latihan untuk membantu anak dalam meningkatkan ketarmpilan toilet training. Metode latihan adalah suatu metode atau salah satu cara untuk mengembangkan kemampuan atau keterampilan siswa dalam aspek kognitif, emosional dan agar mereka menjadi mahir dalam bidangnya. Latihan ini bisanya dilakukan setelah siswa memahami suatu materi yang telah dijelaskan oleh guru. Berlatih juga memperoleh keterampilan tertentu. Metode latihan (drill) ialah suatu teknik yang dapat diartikan sebagai suatu cara mengajar dimana siswa melaksanakan kegiatan-kegiatan latihan, agar siswa memiliki kecakapan atau keterampilan yang lebih baik. Latihan yang praktis, mudah dilakukan serta teratur melaksanakannya membina anak dalam meningkatkan penguasaan keterampilan itu, bahkan siswa dapat memiliki ketangkasan itu dengan sempurna (Sulastri, 2019). Metode latihan ialah teknik mengajar yang baik dengan menanamkan kebiasaan kepada siswa untuk memperoleh keterampilan, ketangkasan, kesempatan dan kecepatan. Segala keterampilan dan ketangkasan mampu dikuasai berkat pola kebiasaan yang sudah ditanamkan pada siswa (Ardiana et al., 2021).

Berdasarkan beberapa pengertian di atas dapat disimpulkan bahwa metode latihan merupakan metode penyampaian materi melalui upaya penanaman terhadap kebiasaan-kebiasaan tertentu ini diharapkan siswa dapat menyerap materi secara lebih optimal. Kata latihan mengandung arti bahwa sesuatu itu selalu diulang-ulang, Ada keterampilan yang dapat disempurnakan dalam jangka waktu yang pendek dan ada yang membutuhkan waktu cukup lama. 
Metode latihan memiliki kelebihan, yaitu: (1) dapat mengembangkan kecakapan berpikir (thinking skill) atau kecerdasan intelektual (2) dapat mengembangkan kecakapan motoris (3) dapat memperkuat mental, terampil mengendalikan diri dan emosi (4) dapat mengembangkan kecerdasan spiritual. selain memiliki kelebihan, metode latihan juga memiliki kelemahan, yaitu: (1) dapat menyita waktu anak, sehingga terjadi kekurangan waktu untuk aktivitas yang lain (2) latihan yang dilaksanakan anak secara berulang-ulang merupakan hal yang menoton dan membosankan (3) dapat melelahkan fisik atau pikiran, bila dilakukan latihan jangka waktu yang lama.

Berdasarakan studi pendahuluan yang diperoleh dari hasil identifikasi awal dan observasi kondisi siswa di kelas dari guru kelas, siswa mengalami kesulitan dalam kebersihan diri (bina diri) salah satunya toilet training. Fakta tersebut mendorong peneliti untuk membantu siswa pada tahap intervensi dengan menggunakan metode latihan untuk meningkatkan keterampilan toilet training di SDIT Luqman Padang.

\section{Metode}

Penelitian ini menggunakan metode eksperimen, dengan pendekatan subjek tunggal atau single subject research (SSR). SSR mengacu pada strategi penelitian yang dikembangkan untuk mendokumentasikan perubahan tentang tingkah laku subjek secara individu. Penelitian ini menggunakan pendekatan single subject research (SSR) dalam bentuk desain A-B-A yang terdiri dari tiga fase, mula-mula kemampuan awal anak dalam melakukan buang air kecil secara kontinyu disebut dengan fase baseline (A1). Kemudian anak diberikan intervensi dengan menggunakan metode latihan (drill) (B). Setelah itu kemampuan anak dalam melakukan buang air kecil kembali diukur disebut fase baseline (A2) yang bertujuan sebagai kontrol bahwa adanya hubungan antara variabel bebas dan variabel terikat (Sunanto et al., 2005). Data dikumpulkan melalui tes perbuatan dengan kriteria penilaian bisa dengan skor 2 , bisa dengan bantuan skor 1 , dan tidak bisa diberi skor 0 .

Pada fase baseline (A1) ialah kemampuan awal dalam melakukan kebersihan diri toilet training, fase intervensi (B) yakni kondisi saat diberi perlakukan melalui metode latihan. Pada fase baseline (A2) yakni kondisi setelah diberikannya perlakuan menggunakan metode latihan. Data perolehan dari setiap kondisi dapat dijadikan sebagai pedoman untuk melihat ada atau tidaknya peningkatan keterampilan toilet training melalui metode latihan.

Teknik yang digunakan dalam pengumpulan data yakni melalui observasi dan tes perbuatan. Tes perbuatan berguna untuk melihat perubahan tingkat kemampuan yang diperoleh peserta didik disetiap kondisi. Setelah diperoleh hasil yang stabil, kemudian data dianalisis ke dalam grafik visual (visual analysis of grafic data) yaitu mengolah data yang telah direkap ke dalam grafik (Sunanto et al., 2005). Analisis data menggunakan dua tahapan yaitu : analisis data dalam kondisi dan analisis data antar kondisi, sehingga diperoleh hasil perbandingan tingkat kemampuan anak dalam meningkatkan keterampilan toilet training disetiap kondisi.

\section{Hasil dan Pembahasan}

\section{A. Hasil Penelitian}

Penelitian ini dilakukan di SDIT Luqman Padang, penelitian ini dilaksanakan dalam enambelas kali pertemuan, dengan menggunakan desain A-B-A, kegiatan baseline (A1) dilakukan dengan mengamati kemapuan awal anak, kegiatan (B) yaitu kegiatan memberikan intervensi, dan kondisi baseline (A2) yaitu kondisi setelah diberikan perlakuan. Hasil penelitian ini 
Jurnal Edumaspul, 5 (2), Year 2021 - 682

(Nurul Afifah, Megaiswari Biran Asnah)

menunjukkan bahwa toilet training melalui metode latihan mengalami peningkatan. Untuk lebih jelasnya bisa dilihat pada keterangan dan analisis penelitian dalam grafik dibawah ini:

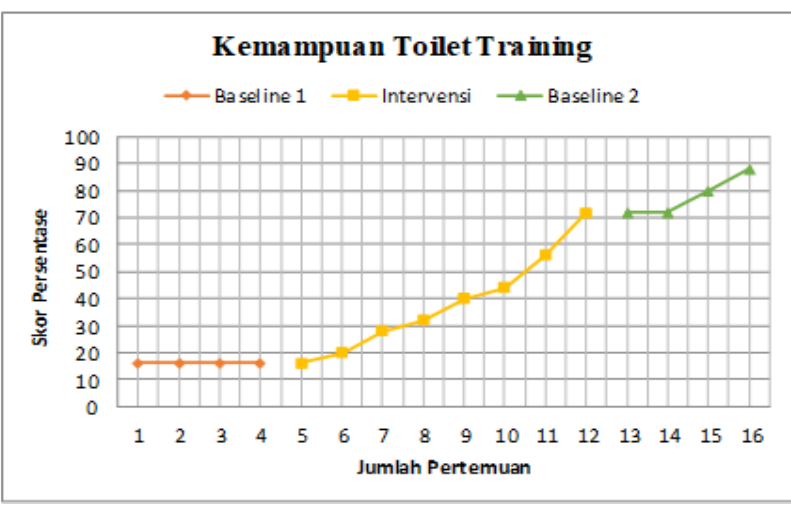

Grafik 1. Kondisi baseline (A1), Intervensi (B), dan kondisi baseline (A2) dalam keterampilan toilet training.

Berdasarkan grafik diatas dapat dilihat tingkat kemampuan anak dalam meningkatkan keterampilan toilet training dilakukan sebanyak 16 kali pertemuan, berikut penjabaran kemampuan yang dikuasai di setiap kondisi :

1. Fase baseline (A1) dilakukan sebanyak 4 kali pertemuan dengan skor: 16, 16, 16, 16. Pada fase baseline (A1) data yang diperoleh sudah stabil.

2. Fase intervensi (B) dilakukan sebanyak 8 kali pertemuan dengan sko rperolehan $16,20,28,32,40$, 44, 56, 72.

3. Fase baseline (A2) dilakukan sebanyak 4 kali pertemuan dengan skor perolehan : 72, 72, 80, 88. Dari data tersebut dapat dilihat kemampuan anak dalam meningkatkan keterampilan toilet training melalui metode latihan. Kondisi anak meningkat setelah diberikan perlakuan dengan menggunakan metode latihan.

\section{B. Pembahasan}

Penelitian ini membahas tentang meningkatkan keterampilan toilet training melalui metode latihan bagi anak autis. Toilet training adalah sebuah pelatihan guna meningkatkan keterampilan anak dalam menggunakan toilet baik untuk buang air kecil maupun besar pada waktu tertentu sesuai dengan perkembangan usia dan kemampuan sosial anak (Nurhasanah, 2016). Latihan penggunaan toilet (toilet training) merupakan upaya proses pengajaran anak sedini mungkin agarmampu mengontrol dalam melakukan BAK atau BAB secara benar dan teratur. Latihan untuk buang air besar dan kecil di toilet adalah suatu hubungan kerjasama dengan adanya peran yang sesuai untuk masing-masing pihak (Pramono \& Risnawati, 2018). Penelitian ini dilakukan terhadap seorang anak autis kelas I SD di SDIT Luqman Padang. Diketahui bahwa kemampuan awal anak dalam meningkatkan keterampilan toilet training melalui metode latihan masih rendah, karena belum sepenuhnya diajarkan. Meningkatkan keterampilan toilet training dapat diajarkan dalam melalui metode latihan.

Keterampilan toilet training merupakan salah satu aktivitas kegiatan sehari-hari yang sangat membutuhkan kemandirian pada anak autis. Anak autis perlu diberikan pengertian dan pengarahan secara sederhana agar lebih mudah dipahami. Pembelajaran toilet training dapat diberikan dengan metode pembelajaran yang tepat. Tujuan diberikannya pembelajaran toilet training secara bertahap agar mempermudah anak autis untuk meningkatkan kemandiriannya. Pembelajaran toilet training ini sangat penting diberikan kepada anak autis agar mampu mengontrol buang air besar/kecil secara baik dan benar di kamar mandi. Selain itu anak autis diharapkan dapat 
menjaga kebersihan dirinya sendiri setelah buang air besar/kecil, serta dapat melepas dan memasang kembali pakaiannya sendiri.

Dalam memberikan pembelajaran harus diawali dari yang mudah, sedikit sulit, hingga ke yang benar-benar sulit agar anak autis mudah memahami materi pembelajaran yang diberikan. Melalui tahapan-tahapan pembelajaran akan lebih menjamin terjadinya kesuksesan yang diperoleh pada proses belajar. Pembelajaran tidak akan dapat dipahami oleh anak autis jika dilakukan hanya satu kali penyampaian, mengingat kemampuan perkembangan fungsi otaknya. Salah satu upaya agar pembelajaran toilet training yang diberikan bagi anak autis berjalan dengan baik yaitu dengan menggunakan metode latihan secara tepat, terarah dan terstruktur, agar dapat sedikit demi sedikit meningkatkan kemandirian toilet training pada anak autis.

Pelaksanaan pembelajaran toilet training melalui pengunaan metode latihan diberikan secara bertahap dan dilakukan berulang-ulang agar anak autis dapat mudah untuk memahami dan mengingat setiap tahapan pada proses pembelajaran toilet training. Terdapat beberapa kelebihan dan kekurangan dari metode latihan. Kelebihan dari metode latihan yaitu waktu relatife singkat, dapat diperoleh penguasaan dan keterampilan yang diharapkan akan tertanam pada setiap pribadi anak dengan kebiasaan belajar secara rutin dan disiplin. Kekurangan dari metode latihan adalah latihan yang dilakukan dalam pengawasan ketat dan serius sehingga dapat menimbulkan kebosanan pada anak.

Setelah dilakukan analisis data diperoleh hasil bahwa, tingkat kemampuan anak dalam keterampilan toilet training melalui metode latihan (drill) sebelum diberikan intervensi masih rendah, akan tetapi setelah diberikan intervensi melalui metode latihan kemampuan anak mengalami peningkatan yakni dapat dilihat pada kemampuan yang dikuasai: membuka celana, mengambil air dengan gayung, mencuci tangan dengan sabun, menyalakan kran hingga memasang celana. Hal ini membuktikan bahwa metode latihan dapat meningkatkan keterampilan toilet training melalui metode latihan bagi anak autis. Pembelajaran toilet training pada anak autis dilakukan harus secara kontinu dan berulang-ulang agar anak dapat mengingat hal-hal kebiasaan tersebut.

\section{Simpulan}

Dari hasil penelitian yang telah dilakukan, dapat disimpulkan bahwa menggunakan metode latihan dapat meningkatkan keterampilan toilet training bagi anak autis. Hal ini dibuktikan dengan data-data perolehan terhadap kemampuan anak disetiap kondisi yakni kondisi baseline 1 (A1), Intervensi (B), dan baseline 2 (A2). Penelitian dilakukan sebanyak 16 kali pertemuan, A1 dilakukan sebanyak 4 kali pertemuan, intervensi (B) dilakukan sebanyak 8 kali pertemuan, dan A2 dilakukan sebanyak 4 kali pertemuan.

Kemampuan anak sebelum diberikan intervensi melalui metode latihan (A1) yakni memperoleh skor: $16,16,16,16$, sedangkan pada saat diberikan intervensi memperoleh skor: 16, 20 ,28, 32, 40, 44, 56, 72 dengan peningkatan yang stabil, sedangkan pada kondisi A2 juga mengalami peningkatan dibandingkan dengan A1 yakni : 72, 72, 80, 88. Dari hasil perolehan data di setiap kondisi, dapat diketahui bahwa kemampuan anak dalam meningkatkan keterampilan toilet training mengalami peningkatan dapat dilihat pada perbandingan kondisi A1 (sebelum diberikan intervensi) dengan kondisi setelah 
diberikan intervensi (A2), sehingga dapat disimpulkan bahwa metode latihan dapat meningkatkan keterampilan toilet training bagi anak autis di SDIT Luqman Padang.

\section{Daftar Pustaka}

(1) Ardiana, D. P. Y., Widyastuti, A., Susanti, S. S., Halim, N. M., \& Herlina, E. S. (2021). Metode Pembelajaran Guru (A. Rikki \& J. Simarmata (Eds.)). Yayasan Kita Menulis. Https://Www.Google.Co.Id/Books/Edit ion/Metode_Pembelajaran_Guru/Mko yeaaaqbaj?HI=Id\&Gbpv $=0$

(2) Irawan, R. (2019). Gangguan Metabolik Otak \& Terapi Nutrisi Pada Anak Autisme. Airlangga University Press.

(3) Khuriyati, S. (2014). Kemampuan Bina Diri Toilet Training Siswa Autis Di Slb Khusus Autis Bina Anggita Yogyakarta.

(4) Nurhasanah, H. (2016). Peningkatan Kemampuan Bina Diri Toilet Training Anak Autis Melalui Metode Latihan (Drill) Di Pusat Layanan Autis Yogyakarta.
(5) Pramono, D., \& Risnawati, A. (2018). Meningkatkan Kedisiplinan Anak Usia Dini Melalui Latihan Pembiasaan Penggunaan Toilet $\mathrm{Di} \mathrm{Kb}$ Al-Hidayah Insan Mandiri Kabupaten Bandung. Jurnal Obsesi : Jurnal Pendidikan Anak Usia Dini, 2(1), 64-69.

(6) Sulastri, E. (2019). 9 Aplikasi Metode Pembelajaran. Guepedia. Https://Www.Google.Co.Id/Books/Edit ion/9_Aplikasi_Metode_Pembelajaran /Z-Medwaaqbaj?HI=Id\&Gbpv=0

(7) Sunanto, J., Takeuchi, K., \& Nakata, H. (2005). Pengantar Penelitian Dengan Subyek Tunggal.

(8) Syarifuddin, S. (2010). Faktor-Faktor Yang Mempengaruhi Kemandirian Toileting Pada Anak Umur 2 - 3 Tahun Di Wilayah Kerja Puskesmas Pangkajene Kabupaten Sidrap. 